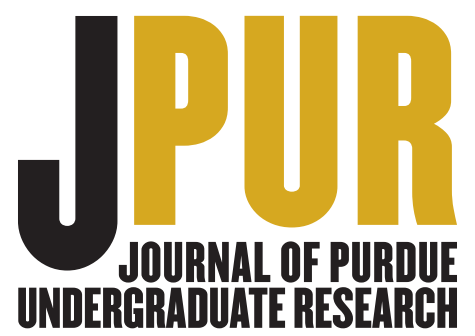

LIBERAL ARTS

\section{America, Divided: Understanding the Contentious Political Climate Following the 2016 Election}

\section{Student researchers:}

Meron Tamene, Pablo Balcazar, and Daniella Gonzalez, Freshmen, Danielle Hustedt, Sophomore, and Courtney Pegues, Junior

Morris P. Fiorina argues in the third edition of his 2010 book Culture War? The Myth of a Polarized America that average American citizens are not as polarized as political pundits and politicians make them seem. This argument served as the basis of our research, as we sought to examine the political perceptions of citizens in post-2016 election America. We ask: Is the United States in the midst of a culture war; and, if so, what factors are contributing to the polarization of conservative and liberal values? At the time of the inauguration, Washington, DC, stood as the epicenter in which all members of the political spectrum could gather together and voice their opinions against the backdrop of one of the most important occasions in American government. Over a span of four days during the Presidential Inauguration, qualitative data was collected in Washington, DC, at inauguration-related events, through participant observation, and via semi-structured interviews - an estimated 220 in all. Respondents represented a wide range of demographics, split between supporters and nonsupporters of the Trump administration. Our interview questions focused on respondents' perceptions of national security, health care, immigration, and the restructuring of political parties. For each issue, activists and members of the political elite had differing opinions on the current state of the nation.

Our data show that respondents believe a culture war does indeed exist. They mostly credit the divide among citizens to the reemergence of nationalistic ideals and the prominence of identity politics in mainstream media and among the political elite. Other findings reveal that respondents have negative perceptions of the media, but these perceptions were paired with hopes of reconciliation. Based on our interviews and observations during inauguration weekend, respondents suggest that there is a series of large-scale ideological divides among the politically active in Washington, DC. Such ideological divides factor into issues of immigration, party politics, race relations, and gender rights. One notion that was shared by the majority of the respondents was the belief that unification of all parties must come about to make change for the better, and that polarization must be minimized. Our findings provide a wider acknowledgment of this polarization, which may allow people on both sides of the political spectrum to adapt to the challenges of American politics, opening a door for solutions that will allow for the lessening of the gap that has been created.

Research advisor Natasha T. Duncan writes: "The research of these students is propitious given the political climate of the United States in recent times. Their findings suggest that we reconsider Fiorina's (2010) conclusions about a culture war in the post-2016 presidential election era."

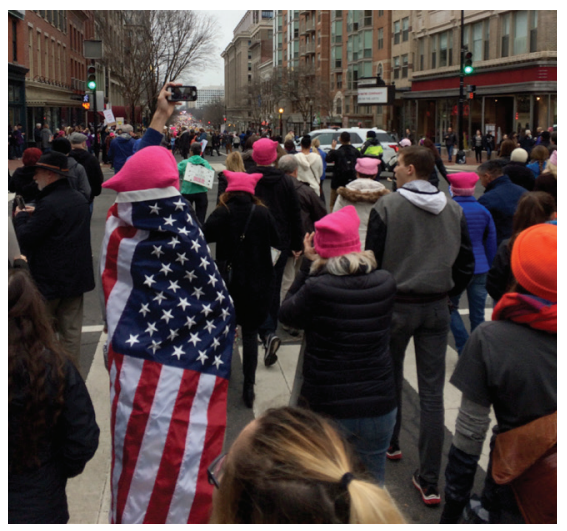

Figure 1. Protesters participating in the Women's March on Washington show their political identity by wearing the "pink pussy" hat. Photo by Danielle Hustedt.

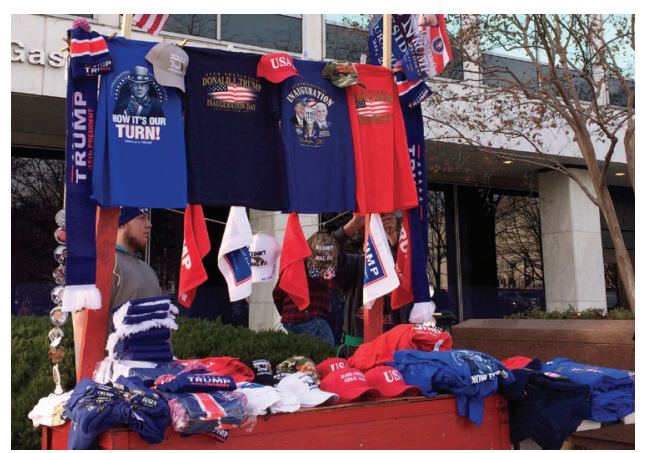

Figure 2. A merchant sells Trump apparel, which boasts patriotic colors and slogans. One shirt reads "NOW IT'S OUR TURN," alluding to the divide among parties. Photo by Meron Tamene. 